\title{
Investigation on the Suitability of Fobur Granite in Jos, Plateau State, Nigeria for Road Construction
}

\section{${ }^{* 1}$ ALABI, OLADUNNI OYELOLA; ${ }^{2}$ OYEDEPO, OLUGBENGA JOSEPH $;{ }^{3}$ ABERE VICTOR DARE}

\author{
${ }^{I}$ Metallurgical and Materials Engineering Department, \\ Federal University of Technology, P.M.B.704, Akure Ondo State, Nigeria \\ ${ }^{2}$ Civil and Environmental Engineering Department, \\ Federal University of Technology, P.M.B.704, Akure Ondo State, Nigeria \\ ${ }^{3}$ National Metallurgical Development Centre, P.M.B. 2116, Jos, Plateau State, Nigeria \\ "Correspondence Author: oladunni69alabi@yahoo.com
}

\begin{abstract}
The suitability of Fobur granite for road construction was investigated. Three samples $\mathrm{A}, \mathrm{B}$ and $\mathrm{C}$ were handpicked from various locations on the quarry site using random sampling method. The samples were subjected to different tests namely chemical analysis, radioactivity, polishability, oxidization properties, porosity, compressive test and hardness test. The chemical analysis of $\mathrm{CaCO}_{3}$ with assays for samples $\mathrm{A}, \mathrm{B}$, and $\mathrm{C}$ are $52.33 \%, 48.5 \%$, and 54. $28 \%$ respectively; specific gravity obtained are $2.07,2.27$ and 2.28 for samples A, B and C. The values of porosity test for samples $\mathrm{A}, \mathrm{B}$, and $\mathrm{C}$ were $0.02,0.03$ and 0.03 ; while Oxidation properties test reported- with no peeling was observed, the polish stone value (PSV) test was for the samples resulted in good abrasiveness and yielding attractive color tints. Also, the polishability test indicated that the samples are good for lapidary; while Radioactivity test estimation were gotten to be $6.8,7.7$ and $8.3 \mathrm{microR} / \mathrm{hr}$. for samples $\mathrm{A}, \mathrm{B}$ and $\mathrm{C}$ respectively. Hence, thevalues obtained from investigation on the suitability of Fobur granite in Jos, Plateau State, Nigeria for road construction are within the accepted equivalent maximum permissible level, suitable for road construction. () JASEM
\end{abstract}

\section{https://dx.doi.org/10.4314/jasem.v21i4.11}

Key words: Granite, Road Construction, Random Sampling, Porosity, Abrasiveness, Radioactivity

The quest for diversification from crude oil to alternative mineral resources by the Federal Government of Nigeria gives room for research into different mineral resources which abounds in large deposits in the country, which is blessed with both solid and industrial minerals. Some of these industrial minerals are Bentonite, Barite, Granite, Quartz, Gypsum, and Limestone among others. Granite which is conceivably the most well-known kind of molten rock can be found in numerous states in Nigeria; be that as it may, it is in abundance in Jos and its environ. The durability property and abundance of granite makes it a preferred choice of minerals over others especially for construction purposes. The primary minerals found in granite include Quartz, Plagioclase, Feldspars, Potassium, Potassium-feldspar, Hornblende and Micas (Amethyst, 2004). Quartz is mostly the last mineral to crystallize and fills in the extra space between the other minerals, its hardness lack chemical reactivity, while lack of cleavages gives granite a significant amount of its desirable durable properties. Granite is actually rather radioactive and has 5 to 20 times concentration of uranium compound to other common rock types (Truswell, 1969). Some health concern exists in areas that are rich in granitic terrain, as background radiation is enhanced by the occurrence of large granite bodies. Although, the uranium is generally not concentrated enough to make granite a uranium ore; the leaching and erosion of granite has helped to produce most of the uranium ore deposits around the world. Quartz is responsible for radon gas, being the by - product of radioactive decay of radium found in all granites. The more quartz, the more radon and radioactivity in the granite (Irfan, 1996; Minipal-4, 2014)

Furthermore, granite is a natural product whose beauty comes from porosity, crystalline quartz structure, fissures, and movement of the conglomerate, mineral composition, veining and grain. Granite is formed by the molten magma deep within the earth under great heat and pressure (Wills, 2006). Granite is very dense and heavy, making a massive countertop, available in large slab sizes and varieties are available from all over the world. It is also a porous material as well as permeable and has massive capillary, leading to cleaning damages, efflorescence, staining, water marks, soap stains, surface haze, bacteria and mold

**Correspondence Author Email: oladunni69alabi@yahoo.com 
colonies resulting in odor and health risks, and sink rail splitting from rod corrosion. Porosity also results to water damage in granite, hydrolysis, and hydration, even bacteria that actually eat the stone.

Granite rocks possess several physical and mechanical properties that might influence the use of granites as a construction material. Generally, granites find applications in structural and civil engineering works. The physical and mechanical properties of granites are functions of its texture and mineralogy (Irfan,1969).The properties may as well affect quarrying operation tunneling mining, slope stability and the use of granite as constructional material (Tugrul and Zarif, 2008). However, the strength of granite rock decreases with increase in water content due to reduction in the coefficient of internal friction of the rock particles (Irfan, 1969).In addition the presence of water in rock increases the deformability of the rock mass (Ojo and Olaleye, 2004). The older granite of Nigeria varies in composition ranging from tonalite, granodiorite, granite, syenite and charnockite rocks (Truswell, 1969).

Previous works in different parts of the Nigerian basement complex shows that the older granites are high level intrusions emplaced by stopping and diapiric process (Fitches et al., 1985). The high regional deformation which followed and preceded the emplacement of the older granite resulted in the pronounced and wide spread of North -South trend (Ametyst, 2014). The older granite in Nigeria have been dated severally at $500-750$ ma (Vanet al, 1985).

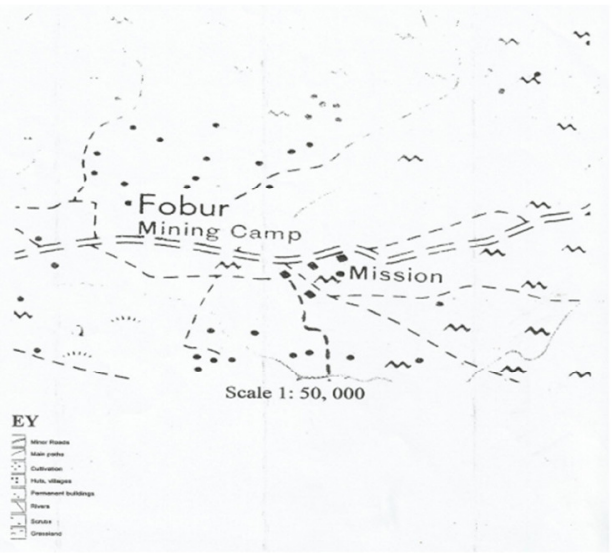

Fig 1: Map of Fobur Village. Source:( Macleod, 1971) rocktype distribution (scale 1: 66667
Geology of the Study Area: The study area lies in central Nigeria. The granite rocks under study are located in Plateau State Fobur village. The Nigerian Basement complex extends westwards and is continuous within the Dahomey-Togo-Ghana region. To the east and the south the basement complex is covered by the Mesozoic-Recent sediments of the Dahomey and Niger Coastal Basins. The Basement complex of Nigeria are composed predominantly of migmatitic and granite gneiss; quartzites; slightly migmatised to unmigmatised metasedimentary schistsand metaigneous rocks, charnockitic, gabbroic and dioritic rocks; and members of old granites, granodiorite and syenites. Granite gneiss are found abundant in Central Nigeria (Kogbe, 1979).

Fobur village is situated in Fobur District, Furaka Area of Jos East Local Government Area of Plateau State, Nigeria. Jos is situated in the central Nigeria basement complex surrounded by rugged terrain of granitic gneiss rocks, hence, the investigation of the granitic rock in Fobur village located nearby to Lende and Kudedu Vilage, about 12 kilometers from Lamingo Dam.It has its headquarters in Angware town with an area of about $1394 \mathrm{~m}^{2}$ and a population of 85,602 at 2006 census (Map Data, 2016). Figure 1is the map of Fobur village while, Figure 2 show the it's geological map

This research work is aimed at investigating the suitability of using Fobur granite sample for road construction and other civil engineering works. 


\section{MATERIALS AND METHODS}

Granite ore samples used in this research work was sourced from three different mining points (A, B and C) in Fobur granite site occupied by Rick Rock Construction Company (RRCC) In Fobur town Jos east local government area of Plateau State, with Coordinate as Latitude N09 ${ }^{\circ} \quad 57^{\prime \prime} \quad 202^{\prime}$ and longitudeE008 $51 " 0 \mathrm{E}$ at an elevation of 1117 meters above the sea level from Fobur Village; Jos East L.G.A, Jos, Plateau State, Nigeria. 20kg of sample from each points were picked using $10 \mathrm{~kg}$ sledge hammer on the rock body to realize boulder size followed by hand picking and finally after further reduction of size by random sampling method. Each sample was subjected to same types of laboratory test: Chemical Analysis, Specific gravity determination, Porosity determination, Oxygen properties test, polished stone value and Radioactivity test measurement using Lude lump Counter, model 19 shown in Figure 3.

Sample Preparations: Three different samples (A, B and $\mathrm{C}$ ) were picked from the deposit occurring in boulders ranging from $50 \mathrm{~mm}$ to $80 \mathrm{~mm}$ diameters. The diameters of the samples were reduced to $2 \mathrm{~mm}$ in succession using Denver Jaw Crusher, Model BDA 15571, type A and Denver Cone Crusher, Model A003,Type 12 shown in Figure 4. However, Deco Roll Crusher model B7141A from the Mineral laboratory of the National Metallurgical Development Centre (NMDC), Jos Nigeria was used to further reduce the sample sizes before using the required quantity.

Chemical Characterization of Granite: $1 \mathrm{~kg}$ of crushed Samples A, B and C were picked using cone and quartering method and were ground for one minute to milling stage using $0.5 \mathrm{~kg}$ capacity Ring Pulverize. The analysis cup was compressed with the rammer into powder briquettes standard for proper mineral count and analysis by the machine; the sample was analyzed for one hour using SpectroXepos Energy Dispersive X-ray Fluorescence Spectrometer (Minipal - 4, 2014). Element found above the detection limit were reported and major elements were expressed as oxides and were analyzed in percentage $(\%)$ composition. This determined the chemical composition of the granites using x-rays.

Specific Gravity Determination of Granite Samples: 10 gms of sample A was weighed (W) using Camry Digital Weighing Balance (Model: Camry 25k5055China), and was charged into $50 \mathrm{mls}$ measuring cylinder of known volume of water refers to as initial volume $\left(\mathrm{V}_{1}\right)$. After settling for five minutes, final volume $\left(\mathrm{V}_{2}\right)$ of water was measured and the difference in the initial volume and final volume of water was noted as the displacement. Specific gravity was calculated using equation (ISRM, 1981)

Specificgravity $=$

$\frac{\text { Mass of granite (g) }}{\text { Displacement value }}$ XDensity of water

$=\frac{W}{V 2-V 1} x$ Densityof water

Porosity Determination of Granite Samples: The samples A, B, C were in seize of cubic, $10 \mathrm{~mm}$ by $10 \mathrm{~mm}$ by $10 \mathrm{~mm}$. The samples were then dried in an oven at $110^{\circ} \mathrm{C}$. The dry weight of the samples in air were taken and recorded as $\mathrm{W}_{1}$, The sample in air was suspended with the aid of a rope in distilled water contained in a $100 \mathrm{mls}$. Pyrex measuring beaker such that the sample did not touch the bottom or sides of the beaker for one hour until the sample in water stopped given off bubbles. The sample was removed from water and extra water was wiped off from its surface by lightly blotting with a wet towel, and was weighted in air as $\left(\mathrm{W}_{2}\right)$. The difference in the weight in air and weight of sample after bubbles have been driven out is known to give porosity of the granite. This procedure was repeated for samples B and C.

Porosity $=$ Weight of sample after the moisture is released $\left(\mathrm{W}_{2}\right)$ - Weight of sample in air $\left(\mathrm{W}_{1}\right)$ .. (3)

$=\mathrm{W}_{2}-\mathrm{W}_{1}$

Radioactivity Test: The Radioactivity test was carried out at Mineral Laboratory of NMDC Jos, to determine the rate of emission of radioactive elements present in the samples and to examine whether the rate of emission of granite would be harmful to man when exposed to such radiation. The test was carried out using Geiger Muller Counter, (Model 19 Micro R-Meter, Ludlum measurements Inc. Sweefwate, Texas) (Figure 3).120 g of granite sample A - was weighed using kern EMD 600 weighing balance in order to have a uniform quantity of granite to be exposed to radiation. The samples were leveled before Ludlum Micro R Meter, model 19 radioactive counter machine was used by placing it on the sample for sixty (60) seconds; after which the Ludlum readings were taken, recorded and tabulated. The same procedure was repeated for samples $\mathrm{B}$ and $\mathrm{C}$ respectively. 


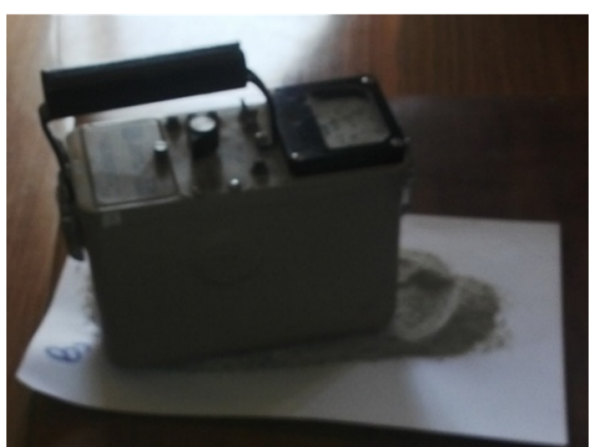

Fig 3: Geiger Muller Counter, (Model 19)

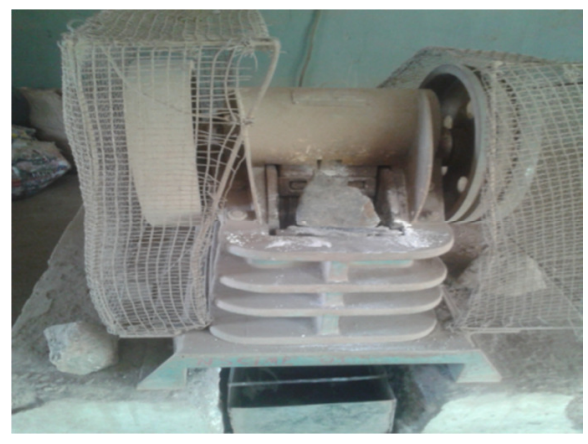

Fig 4: Denver Jaw Crusher (Model: BDA 15571)
Oxidation Properties Test: This test was carried out to determine the rate of composition or break down of the rock samples surfaces when exposed to air, heat, and acidic solvent before and after polished. The procedure used for the test includes: Granite sample A, B and C of dimensions $20 \mathrm{~mm}$ X $20 \mathrm{~mm}$ X $20 \mathrm{~mm}$ were polished before exposed to prepared solution of tap water, dilute hydrochloric acid (HCL) and oil. These samples were then left exposed to atmospheric condition for four (4) days. After this the samples were then re-introduced into a synon-electro-magnetic machine corporation (FMC) with variable speed of 250rpm (Maximum) to allow re polishing of the oxidized surface. Finally, the samples were removed from the machine, cleaned with Oxygen damp paper of grade one (1) and dried with pressurized air. The dried samples were then observed under a Nikkonophiphot polarized microscope for any damage to the already polished surface such as peeling due to the corrosive nature of the solution of acid, air and oil.

Mechanical Property of Granite: Samples of $20 \mathrm{~mm} x$ $20 \mathrm{~mm} \times 20 \mathrm{~mm}$ were prepared to be used in testing the mechanical properties of Fobur granite samples A, B and $\mathrm{C}$ from the three different locations. The mechanical properties investigated were compressive strength and hardness.

Compression Test: Compression stress was measured using form test seidner, model GMBH D7940 compression machine, Riedlingen - West Germany.Compressive stress was applied uniaxially to sample of dimension $20 \mathrm{~mm} \times 20 \mathrm{~mm} \times 20 \mathrm{~mm}$ with a crosshead speed of $20 \mathrm{~mm}$ per minute to determine the behavior of the composites under a compressive load. The test was carried out at the Mechanical Testing Laboratory of National Metallurgical Development Centre (NMDC), Jos.

Hardness Test: The hardness test was carried out on the sample of dimension $20 \mathrm{~mm} \times 20 \mathrm{~mm} \times 20 \mathrm{~mm}$ using a Rockwell Hardness Testing Machine (Model: GMBH
3806) with steel ball as the indenter at the Mechanical Testing Laboratory of NMDC, Jos. The indentation was carried out on five randomly selected points on the surface of each sample, average of the hardness value was taken and reported.

Polish Stone Value (PSV) Test: The polish test was carried out on $20 \mathrm{~mm}$ x $20 \mathrm{~mm}$ x $20 \mathrm{~mm}$ granite samples to determine the display of good abrasiveness and yielding attractive color tints at the Metallography Laboratory of NMDC, Jos. The samples were placed at $90^{\circ}$ and was pre-polished to remove saw mark and other uneven surfaces using abrasives of different size grade ranging from $240,320,400$, and 600 . The pre-polishing slabs were immersed into accurate manufacture moulds and thereafter removed and placed on "Road wheels" of Accelerated Polishing Machine (EcometII), slurry abrasive of grade 1: 200 were continuously fed through fixed mechanical feeders. Flow emery was then loaded on tyre wheel by a spring loader spreader plate with the corn emery directly debating fed to the specimen through a feed chute and introducing water at a controlled rate. Using a mechanical device, the 'tyre wheel' was then raised and lowered to the 'read wheel'. The revolution counter was fitted to $325 \mathrm{rpm}$ and polishing was allowed for about 25 minutes. The completed polished slabs were removed and washed using distilled water to remove contaminants and was dried using pressurized air. After drying, the slabs were then viewed under a "Vicker Misa" microscope for micro-structural analysis as shown in Figure 5 and 6.

\section{RESULTS AND DISCUSSION}

Tables 1-7 show the results of specific gravity, Porosity value, Compressive strength, Percentage $\mathrm{CaCO}_{3}$, Hardness value, Radioactivity value and the Polish ability value of Fobur granite in Jos, Plateau state respectively. Figure 5 and Figure 6 are the polished granite samples and Microstructure of Fobur granite sample, respectively 
Table 1: Specific Gravity of Fobur Granite in Jos, Plateau State Nigeria

\begin{tabular}{|c|c|c|c|c|c|c|}
\hline Sample & $\begin{array}{c}\text { Mass } \\
(\mathrm{g})\end{array}$ & Initial Volume $\left(\mathrm{v}_{1}\right) \quad\left(\mathrm{cm}^{3}\right)$ & $\begin{array}{l}\text { Final Volume } \\
\left(\mathrm{V}_{2}\right) \\
\left(\mathrm{cm}^{3}\right)\end{array}$ & $\begin{array}{c}\text { Change in Volume }(\Delta v) \\
\left(\mathrm{cm}^{3}\right)\end{array}$ & $\begin{array}{l}\text { Specific } \\
\text { Gravity (SG) }\end{array}$ & $\begin{array}{l}\text { Average } \\
\text { Specific } \\
\text { Gravity }\end{array}$ \\
\hline$\overline{\mathrm{A}_{1}}$ & 10.00 & 20.00 & 25.00 & $\overline{5.00}$ & 2.00 & \\
\hline $\begin{array}{l}\mathrm{A}_{2} \\
\mathrm{~A}_{3}\end{array}$ & $\begin{array}{l}10.00 \\
10.00\end{array}$ & $\begin{array}{l}20.00 \\
20.00\end{array}$ & $\begin{array}{l}24.75 \\
24.75\end{array}$ & $\begin{array}{l}4.75 \\
4.75\end{array}$ & $\begin{array}{l}2.11 \\
2.11\end{array}$ & 2.07 \\
\hline$B_{1}$ & 10.00 & 20.00 & 24.75 & 4.75 & 2.11 & \\
\hline $\mathrm{B}_{2}$ & 10.00 & 20.00 & 24.25 & 4.25 & 2.35 & 2.27 \\
\hline $\mathrm{B}_{3}$ & 10.00 & 20.00 & 24.25 & 4.25 & 2.35 & \\
\hline $\mathrm{C}_{1}$ & 10.00 & 20.00 & 24.50 & 4.50 & 2.22 & \\
\hline $\mathrm{C}_{2}$ & 10.00 & 20.00 & 24.00 & 4.00 & 2.50 & 2.28 \\
\hline $\mathrm{C}_{3}$ & 10.00 & 20.00 & 24.75 & 4.75 & 2.11 & \\
\hline
\end{tabular}

Table 2: Porosity of Fobur Granite in Jos, Plateau State Nigeria

\begin{tabular}{cccccc}
\hline Sample & $\begin{array}{c}\text { Weight in air } \\
\left(\mathrm{W}_{\mathrm{a}}\right)(\mathrm{g})\end{array}$ & $\begin{array}{c}\text { Weight in } \\
\text { water }\left(\mathrm{W}_{\mathrm{w}}\right)(\mathrm{g})\end{array}$ & $\begin{array}{c}\text { Volume of void space } \\
\left(\mathrm{V}_{\mathrm{v}}\right)\end{array}$ & $\begin{array}{c}\text { Porosity } \\
(\varnothing)\end{array}$ & Average porosity \\
\hline $\mathrm{A}_{1}$ & 0.53 & 0.54 & 0.01 & 0.02 & \\
$\mathrm{~A}_{2}$ & 0.63 & 0.64 & 0.01 & 0.02 & 0.020 \\
$\mathrm{~A}_{3}$ & 0.58 & 0.59 & 0.01 & 0.02 & \\
$\mathrm{~B}_{1}$ & 0.94 & 0.96 & 0.02 & 0.02 & 0.027 \\
$\mathrm{~B}_{2}$ & 0.89 & 0.92 & 0.03 & 0.02 & \\
$\mathrm{~B}_{3}$ & 0.78 & 0.80 & 0.03 & 0.03 & \\
$\mathrm{C}_{1}$ & 1.54 & 1.58 & 0.03 & 0.03 & 0.029 \\
$\mathrm{C}_{2}$ & 1.77 & 1.79 & 0.01 & 0.01 & \\
$\mathrm{C}_{3}$ & 1.62 & 1.65 & 0.02 & 0.02 & \\
\hline
\end{tabular}

Table 3: Compressive Strength of Fobur Granite in Jos, Plateau State

\begin{tabular}{cccc}
\hline Sample & $\begin{array}{c}\text { Maximum compressive } \\
\text { Load (MPa) }\end{array}$ & $\begin{array}{c}\text { Compressive Stress } \\
(\mathrm{MPa})\end{array}$ & $\begin{array}{l}\text { Mean Compressive } \\
\text { Stress (MPa) }\end{array}$ \\
\hline A1 & 5.75 & 150.20 & 154.43 \\
A2 & 5.80 & 159.76 & \\
A3 & 6.20 & 153.32 & 198.65 \\
B1 & 8.35 & 198.64 & \\
B2 & 8.48 & 199.42 & 185.12 \\
B3 & 8.09 & 197.90 & \\
C1 & 6.45 & 164.54 & \\
C2 & 7.60 & 196.74 & \\
C3 & 7.30 & 194.09 & \\
\hline
\end{tabular}

Table 4: Percentage $\mathrm{CaCO}_{3}$ of Fobur Granite in Jos, Plateau State Nigeria

\begin{tabular}{lll}
\hline Sample & $\% \mathrm{CaCO}_{2}$ & Remarks \\
$\mathrm{A}$ & 52.23 & Excellent \\
$\mathrm{B}$ & 48.50 & Excellent \\
$\mathrm{C}$ & 54.28 & Excellent \\
\hline
\end{tabular}

Table 5: Hardness Value of Fobur Granite in Jos, Plateau State Nigeria

\begin{tabular}{ccc}
\hline Sample & Hardness & Average Hardness \\
\hline A1 & 87.20 & 87.23 \\
A2 & 87.00 & \\
A3 & 87.50 & \\
B1 & 93.10 & 93.23 \\
B2 & 93.00 & \\
B3 & 93.60 & \\
C1 & 89.50 & 89.30 \\
C2 & 89.30 & \\
C3 & 89.10 & \\
\hline
\end{tabular}


Table 6: Radioactive Value of Fobur Granite in Jos, Plateau State Nigeria

\begin{tabular}{|c|c|c|c|c|c|c|}
\hline Samples & $1^{\text {st }}($ Micro R/hr) & $2^{\text {nd }}$ (Micro R/hr) & $3^{\text {rd }}($ Micro R/hr) & $4^{\text {th }}$ (Micro R/hr) & $5^{\text {th }}$ (Micro R/hr) & $\begin{array}{l}\text { Average count } \\
\text { (Micro R/hr) }\end{array}$ \\
\hline $\mathrm{A}$ & 5.0 & 5.5 & 6.0 & 6.5 & 11 & 6.8 \\
\hline B & 9.5 & 11.5 & 6.5 & 5.5 & 5.5 & 7.7 \\
\hline C & 7.5 & 11.5 & 7.5 & 8.5 & 6.5 & 8.3 \\
\hline
\end{tabular}

Table 7: Polishability Value of Fobur Granite in Jos, Plateau State Nigeria

\begin{tabular}{ccc}
\hline Sample & Polish ability & \multicolumn{1}{c}{ Remarks } \\
\hline A & 92 & Excellent for lapidary \\
B & 94 & Excellent for lapidary \\
C & 96 & Excellent for lapidary \\
\hline
\end{tabular}

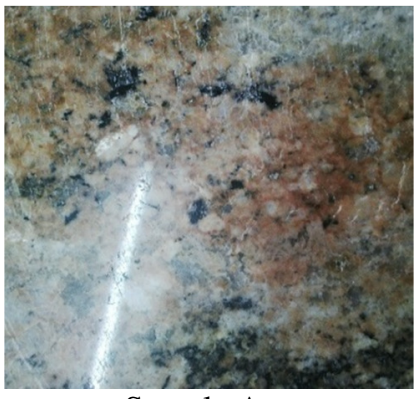

Sample A

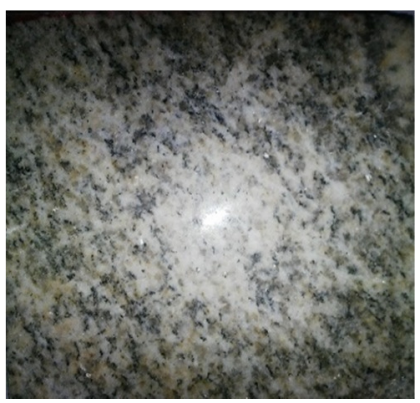

Sample B

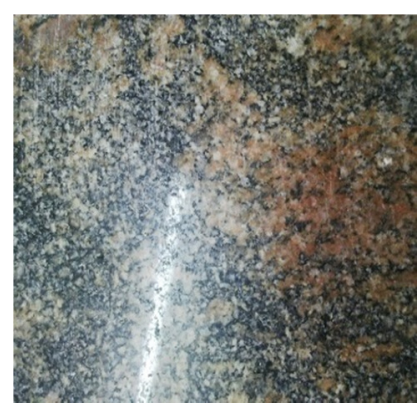

Sample C

Fig 5: Polished Granite Samples from Fobur.

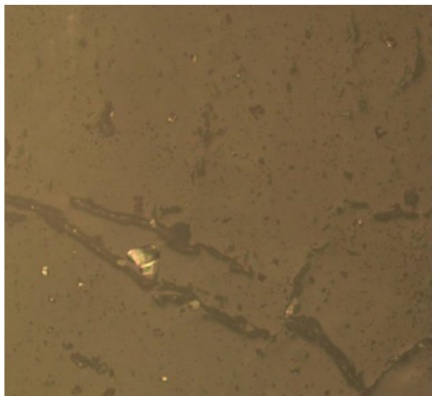

Sample A

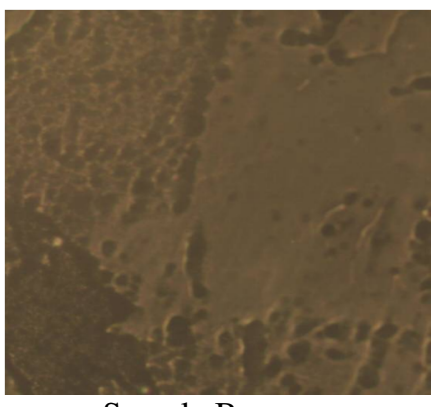

Sample B

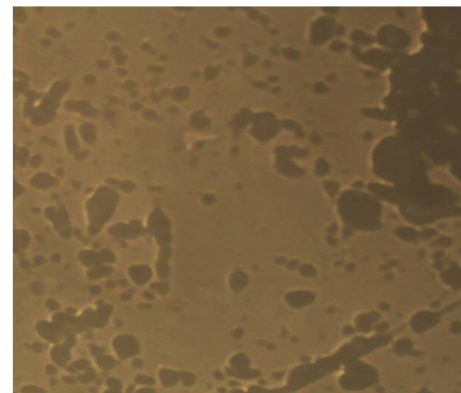

Sample C

Fig 6: Microstructure of Granite Samples from Fobur.

Engineering geology on block production employs geological information combined with practice and experience to assist the engineer in the solution of problems in which such knowledge may be applicable. Therefore, for rock survey to be useful, other than quarrying for estimates or blocks (dimension stone), their engineering properties such as the physical and mechanical properties needs to be investigated.

The high density of the granite material make a substantial top but lead to worker injuries, even deaths from slabs falling on workers. The density also makes granite a heat sink, so any hot pots set on a granite top will transfer heat quickly, resulting in burns from homeowners touching the granite where the pot had set just a short time before. High heat will also damage the stone itself, causing quartz crystals to expand and pop out, even cracking the stone itself from excessive and rapid heat expansion.

Table 1 gives the results of the specific gravity of the granite samples, from this it can be deduced that both samples $\mathrm{A}, \mathrm{B}$ and $\mathrm{C}$ have almost uniform specific gravity: 2.07,2.27 and 2.28 respectively, whichare within the range of the standard specific gravity of granite (2.20); (Wills, 2016). Table 2gives the result of the porosity test on samples A,B and C., with average values $0.020,0.027$ and 0.029 respectively. This shows thatsample $\mathrm{C}$ is more porous than sample $\mathrm{A}$ and $\mathrm{B}$, but are all within the standard porosity value of granite ranges from 0.01 to 0.02 (i.e.1.0 to $2.0 \%$ ); (Broch and Franklin, 1972). Table 3 shows the compressive strength test result of the three samples under study, where samples A, B and C show good compressive strength of $154.43, \quad 198.65$ and $185.12 \mathrm{MPa}$ 
respectively. However, sample $\mathrm{B}$ has the maximum compressive strength. All the values of the compressive strength fall within the range of the compressive strength of granite which ranges from 146.63 $\mathrm{MPa}$ to 197.00 MPa according to Broch and Franklin (1972).Thus, Finally, Table 4 shows the granite Calcium carbonate composition of Sample A - 52.23\%, Sample B - 48.50\%, Sample C - 54.28\%; this shows that the granites contain minimum required standard of calcium carbonate require to be identified as Gneiss Granite (Abuqubu, et al., 2016).This granite under study will withstand the rigor on road construction (hakkl, 1971; Wills, 2006). Table 5, is the result of the hardness testing, which shows that Samples A, B and C have high hardness value of $87.23,93.23$ and 89.30 HBR respectively, but sample $B$ has the highest maximum hardness value of 93.23 and thus, shows that the sample is hard enough for a road constructional work(Ojo and Olaleye, 2004)

Table 6 reveals that all the granite rocks samples were slightly radioactive with values as $6.8,7.7$ and 8.3 microR $/ \mathrm{hr}$., this could be as a result of the present of quartz in the samples. Sample A is associated with little quartz when compared to $\mathrm{B}$ and $\mathrm{C}$ and hence low radioactive rate while $\mathrm{C}$ has the highest radioactive rate as a result of its large amount of quartz in it (ASTM, 2012). Furthermore, Table 7, gives the luster value test on the slabs with polish ability values of 92,94 and 94 respectively and shows excellent lapidary. Figure 1: shows the polished section of the granite samples A, B, and $\mathrm{C}$ which reveals that samples $\mathrm{B}$ and $\mathrm{C}$ display more attractive color tint than sample A., which relatively shows that apart from the use of this granite for road construction, it can as well be used as floor tiles which will beautify floors of a leaving house and it is durable (Abuqubu, et al., 2016).

Figure 2, Shows the micrograph of the microscopic analysis of samples A,B and $\mathrm{C}$ which are the metallurgical microscope images taken at a magnification of X500 show the interactions of the constituent minerals in granite. It can be observed that there is a possible force of adhesion interaction between the metal coordination interactions of granite. This interaction might be responsible for the higher mechanical strength of the granite samples. The interfacial bonding between the constituent minerals of granite plays a prominent role in determining the ultimate mechanical property of the granite as well as its beauty nature. A strong interfacial bonding between the constituent minerals enables the granite to attain better mechanical properties (ASTM, 2016). The chemical interactions and compatibility between the constituent minerals of granite samples result in homogeneous microstructures which lead to strong bond strength between the minerals (Wills, 2006).

Conclusions And Recommendation: From the results of these work, the following conclusions can be drawn: (a) The three tested granite rocks samples possessed a very high physical and mechanical properties that can be used for engineering applications such as structural and building; (b) From the radioactive test, the granite samples prove conclusively that the rate of radiation found occasionally in a slab of granite is not harmful to humans when exposed to it; (c) From the polish-ability test, it shows that the three (3) granite outcrops are suitable for the production of granite floor, wall tiles and most especially for structural works.

It is therefore, by the results, discussion and conclusion of this research work, it is recommended to use Fobur granite mineral for road construction and tiles production.

Acknowledgement: The authors would like to appreciate the kind support of the Management and staff of National Metallurgical Development Centre (NMDC) Jos, Ric Rock Construction Company, Fobour. Jos.

\section{REFERENCES}

Abuqubu, J., Al Dwairi, R. A., Hadi, N.A., Merkel, B., Dunger, V.; Laila, H.A. (2016) Geological and Engineering Properties of Granite Rocks from Aqaba Area, South Jordan. Geomaterials, 6, 1827.http://dx.doi.org/10.4236/gm.2016.61002

American Society for Testing and Materials (ASTM) 170. Standard Test Method for Compressive Strength of Dimension Stone (2008).

American Society for Testing and Materials (ASTM) D2845. (2012). Standard Test Method for Laboratory Determination of Pulse Velocities and Ultrasonic Elastic Constants of Rock. 1(2):45.

Amethyst Galleries Inc. Mineral gallery. (2014). 2(1) $21-23$

Berridge, N.G. (1971). The Jarawa Complex and the G e o $1 \mathrm{~m}$ of the J o s Plateau, Bull Geol. Survey of Nigeria, 2 (32): $85-87$.

Broch, E.; Franklin, J.A. (1972). "The Point-load Strength Test".Int. J. Rock Mechanics \& Mining Science, 9(6): 669-97.

Fitches, W.R., Ajibade, A.C., Egbuniwe, I.G., (1985). R.W. Holt \& J.B. Wright. Late Proterozoic schist 
belts and plutonism in N.W. Nigeria. J. Geol. Soc. London 142: 319-337.

Granite material and industry problems (2016). www.Granitemat.com - retrieved (23/06/2016)

Hakkl W., (1971). The Mineral Exploration of the Aqaba Granites. The Hashemite Kingdom of Jordan. Natural Resources Authority, Mineral Resources Division Report, 31, 45 - 56.

Irfan, T.Y. (1996) Mineralogy, fabric Properties and classification of weathered granites in Hong Kong. Quarterly Journal of Engineering geology. 29(1): 5-35.

ISRM. Rock Characterization, Testing and Monitoring". In: Brown, E.T. (ed.). ISRM suggested methods. Commission on Testing Methods, International Society for Rock Mechanics (ISRM), Pergamon Press, Oxford, UK. (1981). $75-105$.

Kogbe, C.A., (1979).Geology of Nigeria. Elizabethan Publishing house Lagos, Nigeria.1:1-10

Macleod, W.N.; Turner, D.C. (1971). The Younger Granite 2a Geology of 30sPlateau, Geol.Survey of Nigeria, 32 (1) 48-90.
Map Data, Google imaginary GNES/Astrim/spotimage - Digital land sat - 1/08/2016, 13:24

Minipal - 4 Model, (2014). Energy Dispersive X- Ray Fluorescence Spectrometry (ED - XRFS) PANanlytical B.V, Lelyegl,7602 E.A, Almelo, the Netherlands. 3-9.

Ojo, O; Olaleye, B.A. (2004) Classification of Ondo State Intact Rock for Engineering purposes. Journal of Science, Engineering and Technology. 11(3): 5753-5759.

Truswell, J.F. Cope, R.N. (1963) The Geology of parts of Niger and Zaria provinces, Northern Nigeria. Published by geological Survey of Nigeria, 29(1): $17-22$.

Tugrul, A; Zarif; I.H. (1999). Correlation of mineralogical and Textural characterization with engineering properties of selected Granite. http.//www.sciencedirect.com/science retrieved. Jan.14, 2008: 303-315.

Van Breemar, O., Pigeon, R. T., Bowden, P. (1977). Age and Isotopic studies of some Pan-Africa granite from central Nigeria. Res., 4, 307-319.

Wills, B.A.M. (2006). Mineral Processing Technology. New York: Elsevier Science and Technology Books. 6 (1) 75- 83. 